\title{
"LIVE LIKE THE SPARROW": VACHEL LINDSAY'S WHITMAN
}

\author{
NICK MASON-BROWNE
}

IT IS NO SECRET that Walt Whitman liked to keep one eye trained on the future. ${ }^{1} \mathrm{He}$ looked to posterity to incorporate and complete what had been attempted in Leaves of Grass. He had in mind, of course, not only the ramifications of Leaves of Grass as an aesthetic project, but also those of the social and spiritual values his book enshrined. This outlook, in fact, animated what was, perhaps, Whitman's most celebrated message to future poets: "I myself but write one or two indicative words for the future, /. . / Expecting the main things from you." 2 The future as envisaged by Whitman tended to be open-ended and indeterminate, but it was not invariably so. In Democratic Vistas, for instance, Whitman speculated about where future poets might come from: "the infant genius of American poetic expression . . . lies sleeping, aside, unrecking itself, in some Western idiom, or native Michigan or Tennessee repartee, or stump speech. . . . Rude and coarse nursing-beds, these."3

In "Thoughts" [1860], a poem which tries to sum up America's then-current state of affairs, and then conjure up the future, the poetic subject looks specifically toward "immense spiritual results future years far West" but is aware, at the same time, that there are problematic moments when "society waits unformed, and is for a while between things ended and things begun" ( $L G 493$ ). In the same poem we are given an instructive glimpse into the fitful, turbulent nature of literary and social change: "these [achievements] of mine and of the States will in their turn be convuls'd, and serve other parturitions and transitions" (493).

With the advantage of hindsight, we now recognize that Whitman's prophetic instincts were, in fact, fundamentally sound. Within a few years of the poet's death in 1892, as Lisa Szefel reminds us, the rough outlines of the Progressive Era, an interval of "parturitions and transitions," were already perceptible. The Progressives effectively cleared the space, she demonstrates, which would be occupied subsequently by High Modernism. ${ }^{4}$ Moreover, their writings, configured by the influence of Leaves of Grass, were a key part of the linkage which connected Whitman to a later generation of innovators - inspired misfits such as Henry Miller and Kenneth Patchen-who would adopt Whitman's values and project them even farther into the future (10-12). 
Szefel makes use of a once-celebrated turn of phrase as a kind of touchstone for her discussion of the Progressives, referring repeatedly to "the Gospel of Beauty." She takes the usage, of course, from Vachel Lindsay's Adventures While Preaching the Gospel of Beauty (1914), the poet's oddbody, ramshackle journal chronicling his experiences as a youthful itinerant, with its distinctive mix of passionately felt but inchoate verse, social commentary, and idiosyncratic evangelism; it reads today like a rough-and-tumble encounter between John Chapman (Johnny Appleseed, one of Lindsay's folk icons) and some of the harsher realities of modern life. ${ }^{5}$ As Szefel would have it, Lindsay's notion, which evolved into the larger concept of a Church of Beauty encompassing not only revitalized aesthetic ideals but also a quest for the "secret of democratic beauty," encapsulated much of the Progressive agenda. ${ }^{6}$ And it pushed back, as did the Progressives themselves, against Andrew Carnegie's galvanizing concept of a Gospel of Wealth (Szefel 3).

Szefel is at pains to show how Whitman served as a significant inspiration to Progressives such as Lindsay (49-52). She does not, however, clinch her argument by pointing out, as she might well have done, that Whitman himself had made reference to "the gospel of beauty" as early as 1851. Speaking to the Brooklyn Art Union, on the evening of March 31, he famously restated Emerson's call to scholars: "To the artist, I say, has been given the command to go forth into all the world and preach the gospel of beauty. The perfect man is the perfect artist, and it cannot be otherwise." ${ }^{7}$ Nor does Szefel delve very deeply into Lindsay's awkward and erratic struggle with Whitman's influence over the course of his literary career, let alone the consequences of that struggle for his own poetic development and that of poetry itself in the Progressive Era and beyond. The scope of her commentary does not, in fact, allow her to do so. But any student of Whitman or Lindsay will naturally want such gaps to be filled.

At the heart of Whitman's lecture ("Art and Artists") was essentially the same disquiet about the cultural effects of materialism which, a generation later, motivated Vachel Lindsay and the Progressives, and which caused Lindsay to be viewed initially as "something of an insurgent." "Whitman makes a point of railing, in fact, at the crass materialism of a certain kind of American: "His contempt for all there is in the world, except money can be made of it; his utter vacuity of anything more important to him as a man than success in 'business'his religion what is written down in the books, or preached to him as he sits in his rich pew, by one whom he pays a round sum, and thinks it a bargain,- - his only interest in affairs of state, getting offices or jobs for himself or someone who pays him" (UPP 245).

At this early stage, Whitman was, it will be remembered, already equating exemplary aesthetic practice with exemplary civic conduct. 
He refers at one point to Rousseau as "one of the noblest apostles of democracy" and consequently "one of the most genuine artists" (243). Elsewhere, with reference to revolutionary paragons such as George Washington and Mazzini, he suggests that "[he] who does great deeds, does them from his sensitiveness to moral beauty. Such men are not merely artists, they are artistic material. . . . A sublime moral beauty is present to them. ... [They] are heroic beauty, the best beloved of art" (246). It is only fair to observe, of course, that Whitman's thinking on this score owed something to Emerson and Longfellow, and that the conflation of aesthetic beauty and its moral counterpart was, in any event, a relatively commonplace part of the furnishings of the Victorian intellect. That is, indeed, what Gay Wilson Allen stresses in his cursory, but judicious, assessment of "Art and Artists."

But Whitman's lecture, beyond its basis in received ideology, also had a distinctive spiritual or mystical aspect which deserves to be considered..$^{10}$ In his full-length study of Kenneth Patchen as a mystical poet, Raymond Nelson argues persuasively that Patchen's mysticism is part of a long-standing American literary tradition which has been nourished and sustained, in large measure, by the great spiritual watershed of Leaves of Grass. ${ }^{11} \mathrm{He}$ identifies what he believes to be the key tendencies of American literary mysticism, several of which are already manifest, implicitly or otherwise, in Whitman's lecture of 1851. Such tendencies include the attempt to define the artist as a heroic figure, a "prophet-priest" attuned to American democratic ideals and acting as both an agent and a "communal voice" for "human goodness" and "perfectibility" $(17,20)$. In this connection, Nelson asserts that "Walt Whitman was the first fully realized example of the poet-priest as hero, and he is still the greatest" (18). Another such proclivity is, of course, the radical blurring of any distinction between the aesthetic representation of experience and experience itself, between Art and Life, which we have just been underscoring. To illustrate the point, Nelson fixes upon Whitman's classic lyrical assertion, "I sing myself," suggesting that what the verse actually signifies is "I create myself by singing." The usage, Nelson suggests, "would thus introduce the theme of the poetic making of life that informs much of Whitman's work" (19).

Another tendency enumerated by Nelson is the mystical poet's characteristic chafing against formal constraints and traditional forms, which are seen as obstacles to self-expression (21-22). This, too, makes itself felt in Whitman's lecture, although in an oblique and tentative way. Whitman's lecture-hall audience would scarcely have been in a position to grasp or appreciate the full significance of the two lyrical passages which the lecturer cited during the course of his remarks: on the one hand, some lines from "Forest Hymn" by Bryant and, on the other, an excerpt from Whitman's own "Resurgemus." Bryant's text, 
composed in blank verse, had, in fact, been reorganized by Whitman on the page so that it conveyed the distinct impression of being something less structured and mechanical, while Whitman's own poem, although making use of some conventional diction and rhetorical devices, was in fact a tentative example of vers libre (UPP 222, 247). ${ }^{12}$

In retrospect, the two lyrical passages, taken together, are suggestive of something really quite remarkable: the seemingly casual, discreet and implicit announcement of an imminent break with the literary past-a transitional shift from relatively loose technical forms to even looser ones, and a crucial moment of artistic hesitation. In 1851, Whitman was already moving in the direction of that signature technical accomplishment which Herman Melville, some years later, would reflect on in The Confidence Man (1857): "a kind of poetry, but in a form which stands in something of the same relation to blank verse which that does to rhyme. A sort of free-and-easy chant with refrains to it." 13 As we shall see, such technical considerations in connection with Whitman have an added (and pointed) relevance to the larger discussion here, pointing as they do to a significant hidden fact about Vachel Lindsay's own textual practice.

Lindsay's own particular notion of a gospel of beauty took shape as part of the "long foreground" to his emergence, during the Progressive Era, as a clarion voice of the New Poetry. It coalesced around three early poetic texts about rural and small-town life, versions of which Lindsay exchanged for food and lodging while on one of his walking tours. ${ }^{14}$ It has been suggested that while Whitman, in "Song of the Open Road," celebrates the idea of unfettered wandering, it was Lindsay who went so far as to put that idea into practice. In pressing this point, one commentator asserts that "With the possible exception of Mark Twain, no American writer of importance has ever geographically experienced the United States as thoroughly as Lindsay did." 15 In pointed reference to John Chapman (Johnny Appleseed), Lindsay himself suggested that Chapman "slept in the hollow tree on the pile of old leaves, and weathered it past 70 years, while the great Whitman lived in houses, and Thoreau was on Walden but a season or two." To Chapman, he argues, "by the test of life rather than writing . . . belongs nearly every worth-while crown of Whitman."16

However overblown or self-serving such assertions might appear in hindsight, they do, in fact, serve to illuminate one of Lindsay's most characteristic tendencies. Where Whitman tends to the abstract, Lindsay tends rather to the concrete and even literal. Where Whitman might deal in soft generalities, Lindsay struggles to provide, albeit with mixed results, a range of hard specifics. At the heart of Lindsay's overall aesthetic project, with its striking and often explicit sociopolitical dimension, is a notion of the Whitmanian word made flesh. 
In "Art and Artists," Whitman invokes the image of ancient Athens as a shining example of the ideal "community" - a civic model against which the character and progress of the American republic might usefully be measured (UPP 244-245). For his part, Lindsay simply took this a bold step further. He located the New Athens concretely and specifically in the small and medium-sized communities of the Midwest; and he was fond of narrowing the focus to his own hometown of Springfield, Illinois. As Lindsay himself put it: "the things most worthwhile are one's own hearth and neighborhood. We should make our own home and neighborhood the most democratic, the most beautiful and the holiest in the world." 17

In attempting to pinpoint what Lindsay stood for, Ann Massa has suggested that he was "a radical, and a worried radical."18 Lindsay's gospel of beauty, she explains, "envisaged beauty conditioning the whole political, social, and physical fabric of the American nation, its communities and its homes" (40). But Lindsay also "envisaged some sort of community as the starting point. ... All his plans ... retained a village ethos" (29). This particular approach to reform, it will be remembered, came to be known as the New Localism, and it served as the linchpin of Lindsay's idiosyncratic and homespun ideology. It allowed Lindsay to place the notion of a "village-city" (the ideal social matrix) together with related concepts such as the "civic gospel," "civic beauty," and a "civic church" under a single rubric (51). It was, needless to say, also the cornerstone of his quirky, uneven prose work, The Golden Book of Springfield (1920), which projected the poet's hometown a hundred years or so into the future.

The most potent adhesive holding together Lindsay's loosely formulated ideas was religious sentiment. One is tempted, in making the inevitable comparison, to propose that Whitman had a certain affinity with non-sectarian mysticism (notwithstanding some Quaker underpinnings), while Lindsay, for his part, was attuned to its sectarian counterpart (notwithstanding a certain receptivity to interfaith pluralism). Putting this another way, Whitman tended towards spiritual inklings and intuitions, the expression of these in open-ended, expansive language, and the appreciation of their personal and social ramifications. Lindsay, for his part, leaned towards prayerful fervor, allegorical constructs, and the enactment of ideals in the here and now. While both poets plainly had a spiritual dimension, it was, of course, Vachel Lindsay, not Walt Whitman, who had periodic "visions," venerated St. Francis, and sought to establish a kind of utopian Church. ${ }^{19}$ At bottom, it is this fundamental discrepancy, I would venture to say, which underlies such broad-gauge contentions as the following: "[Whitman's] view of America's future was magnificent but hazy; Lindsay, by comparison, seems to be a practical and plebeian theorist and much more of a folk- 
poet" (VL 244). In essence, we are talking only about a difference of emphasis; yet it is a telling and significant difference. In sum, Whitman and Lindsay represent two markedly different permutations of spiritual experience and inquiry, and two quite distinct versions of the mystical poet-hero; and yet they are like two faces of a single coin.

Coming back to Whitman's lecture, Herman Melville, for one, did not put much stock in the kind of aesthetic program that engaged the poet's interest in 1851. Melville associated that kind of thinking, along with its implications for poetry, with Emerson and Transcendentalism, and he famously poked fun at it: "For poetry is not a thing of ink and rhyme, but of thought and act, and, in the latter way, is by anyone to be found anywhere, when in useful action sought. In a word, my disciple here is a thriving young merchant, a practical poet in the West India trade" (CM 235). But the fact is that Whitman juxtaposed and equated textual and civic practice, aesthetic and moral considerations, the spiritual and the political, in ways that went far beyond sophistry; they were, and continue to be, powerful and attractive constructs. It is hardly surprising that they should resonate in so much of Lindsay's thinking and writing.

As a Progressive, Lindsay was, of course, as interested in social reform as in the revitalization of poetry; indeed, he saw the two as aspects of a single initiative. The New Poetry was to be an incarnation of the Gospel of Beauty, and "[that] gospel tried to take away the national preoccupation with material goals . . . and to replace it with a way of life based on the priorities of . . Religion, Equality, and Beauty" (VL 48). Thus, the aesthetic, the spiritual, and the social were deftly folded into a single ideological proposal. In a way reminiscent of Whitman, Lindsay defined beauty in terms of "democracy's beauty-sense." ${ }^{20}$ And he made no firm distinction between artistic beauty and "the human beauty of egalitarian moral conduct" (91). In order to further the Gospel of Beauty, Lindsay asserted, "We must have many Lincoln-hearted men." And as regards such individuals, we are told that "The beauty of thoughtfulness, planning, and cooperation was within their scope. . . . Good citizens, everyday humanitarians, were, by definition, beautiful people" (93).

There was, then, a certain overlap in the thinking of the two poets. But the similarity, I would venture to say, runs considerably deeper. On the most fundamental level, the implicit structure and orientation of Lindsay's textual practice are, in fact, analogous to those of Whitman's poetry. In essence, Whitman's lyrical achievement had, it will be recalled, two dimensions or axes. On its discursive axis, it involved a broadening of the poem's scope to encompass the norms and devices of prose discourse - most notably, those related to oratory and to discursive forms such as the stump speech, the sermon, the newspaper editorial, 
and the lecture. On its formal axis, it entailed a radical loosening of the rules governing prosody and rhyme in a way anticipated by blank verse, prose translations of epic poems, and the various extant kinds of "prose poetry," including the prose of the Bible. It was the convergence and intersection of the two axes which made possible Whitman's historic breakthrough.

When we turn to Lindsay's poetry, we find a fundamentally similar undertaking. Lindsay sought in his own way to broaden the discursive scope of the "genteel poetry" that still dominated the American literary scene when he was struggling to find his lyrical voice. ${ }^{21} \mathrm{He}$ deliberately set out to enlarge that scope so that it could comfortably accommodate the vernacular of the camp meeting, the carnival, the Vaudeville performance, the political rally, the modern factory and its urban setting. At the same time, he reordered the inner workings of the poem, drawing on the flexible, improvised rhythms of jazz and popular dance-steps, as well as adapting folk enablements from sources such as the call-andresponse of the African-American church service, the college yell, and children's sing-song games. He envisaged the poem as something as vividly and powerfully compelling as a popular song or a dance craze, yet invested with literary values and a reformist impulse.

Such was the basis of Lindsay's own breakthrough of 1912-1913. That his particular technical advance should mirror that of Whitman elicits surprise today only because of the long-standing and unshakeable assumption that Lindsay, as a versifier, produced a rudimentary and ungainly form of crambo. As we shall see, he did not. Uncomfortable at times about his own debt to Whitman, William Carlos Williams left us the wise dictum, "The only way to be like Whitman is to write unlike Whitman . . . to be a poet one must be himself!" 22 Lindsay, I would contend, did precisely that. He was, in retrospect, a transitional figure who opened the poem up to popular experience with all of its disquieting energy and rough edges; and he experimented with prosody and rhyme in a way calculated to reach the same mass audience that Whitman had once dreamed of reaching. He was distinctively himself-at its best, his lyrical voice is strong, authentic, and unmistakably American - and yet he also helped to clear a space for a new lyrical practice, and for Whitman's innovations, in the twentieth century.

It has become almost customary to see Lindsay's literary career as a grim cautionary tale about the price of popular acclaim. Lindsay is, one might say, to literary success what Thomas Chatterton once was to penniless obscurity. But Lindsay was, on balance, one of the luckiest poets who ever lived. For one thing, his timing was miraculously perfect. His technical breakthrough came precisely at the most opportune possible moment, when the enervation and mediocrity of the "genteel poetry" which dominated the American literary scene after Whitman's 
death had come to be perceived as a pressing and nettlesome difficulty, and when there was a sharp appetite for literary experimentation and renewal. From the outset, he was afforded active encouragement and support by important magazine editors like Harriet Monroe and by poets as celebrated as W.B. Yeats. ${ }^{23}$ And even during the harsh, chaotic period when he was groping to find his way, Lindsay had been informally praised for his "wild music." 24 Indeed, William James, responding to a letter from the then young and unknown mystical writer, had addressed him as a "brilliant being." 25

Furthermore, Lindsay's recitals, impelled by his populism and evangelical propensities, were electrifying, with the result that he gained access to a mass audience and became, for a time, the most celebrated poet in America. As late as 1928, when Lindsay's heyday was long since over, a reviewer depicted his stage presence as that of "[a] giant who is storming along toward heaven and trying to drag the whole boiling world behind him." ${ }^{26}$ The fact is that, in terms of sheer popularity, we simply have no equivalent figure today, with the possible exception of Leonard Cohen.

Lindsay had a patchy education and the temperament of an outsider artist or literary primitive. He was a willful, scattershot poet. Yet, once established as an important new voice, he was given scope to publish virtually every line of verse he had a mind to preserve, and a good deal more besides. The eight volumes of poetry he produced between 1913 and 1929, together with two editions of his Collected Poems (1923 and 1925) and five prose works, are a remarkable testament to the broad licence he was given to express himself. Even plainly self-indulgent or dubious projects, such as The Golden Book of Springfield or The Litany of Washington Street, went duly to press. Moreover, the reviews of such books, over the course of Lindsay's literary career, were largely positive or, failing that, offered a carefully measured assessment. It is true that, even today, Conrad Aiken's hostile remarks in print about Lindsay and his work have something like the solemn resonance of a death sentence; yet even Aiken was prepared to concede that Lindsay's work had its merits. ${ }^{27}$ In fact, Aiken's critique, for all its caustic frankness, was sufficiently accomodating that, years later, Lindsay could still refer to his fellow-poet as "Conrad" and wistfully allocate Aiken to a special category of "loyal friends" whom he had somehow managed to antagonize. ${ }^{28}$

Perhaps the simplest way to place Lindsay's career in proper historical perspective is to compare it with that of the celebrated film director, D.W. Griffith. As it happens, the two men were of the same generation, both had Kentucky roots, and both of them inherited sectional grievances from the era of the Civil War. Griffith's best years (1913-1921) corresponded roughly, in fact, with those of Lindsay (1913-1922). As artists, moreover, both of them found ways to engage the enthusiastic interest 
of a mass audience, and both had a distinctively American vision with a heavy, didactic grounding. Both were modern innovators with Victorian sensibilities, both indulged in the same curious, chivalric veneration of angelic waifs, and both had perspectives on racial identity which would now be considered insensitive or abhorrent. They were acquainted with, and respected, each other's work. Furthermore, Griffith and Lindsay experienced a similar artistic decline in the mid to late 1920s, and essentially for the same reasons. They had gradually lost touch with the public during a time when the national life changed drastically, and they had already said, in essence, everything they had to say. ${ }^{29}$ It was, perhaps, no accident that, in a moment of existential doubt, Lindsay remarked that he would be "forgotten like an old Biograph film." 30

G. K. Chesterton once characterized Lindsay as "the most national poet [of America] and the one with the most normal energy of literary genius since Walt Whitman." Such an evaluation was consonant with the generally enthusiastic reception of Lindsay in England, where Whitman had been recognized as a "new note," and where Lindsay was now seen as "riding a real Pegasus, an animal that went of itself . . . over the plains of America." ${ }^{11}$ Of course, such assessments do not mesh at all with the scholarly consensus about Vachel Lindsay today. If anything, there is an inclination to write him off altogether, underpinned at times by a vague, but nagging, sense of impatience. ${ }^{32}$ In large measure, this is no more than a reflection of the vagaries of taste and literary fashion over time. In fact, looking at the whole compass of Lindsay's life, it is hard to imagine an approach to poetry more irreparably at odds with the implicit regimen of aims and methods which is favored today. By a curious irony, Lindsay may well be, at this juncture, more of an outsider or insurgent than ever before-which is to say, perhaps, that he has come full circle at last. But Lindsay, like Kenneth Patchen, is also, on some level, subject to a kind of ill-defined, vestigial resentment, if only because something about both poets - related, perhaps, to their self-righteous obduracy or relative lack of intellectual polish-has always rankled.

Yet the fact remains that Lindsay was able to throw an indisputably forceful, and accurate, punch as a literary figure, a punch which can still be felt today on several levels. For one thing, he left behind a tiny, but durable, corpus of classic American poems. The nucleus of that legacy consists, by my reckoning, of "The Kallyope Yell," "The Apple-Barrel of Johnny Appleseed," and several other lyrical texts, perhaps ten in all. The poetry in question is not, at least on its surface, like anything Whitman wrote, nor is it like the work of any other American poet, for that matter; it stands, in its happiest moments, resolutely and confidently on its own two feet. Over the long haul, I would gently suggest, the distinctively American dynamism and originality which such a body of poetry incorporates cannot be written off. 
More importantly, perhaps, the totality of Lindsay's lyrical output had the effect of preparing the way for a new, revitalized textual practice with an innovative and populist thrust. Whatever he may have thought or said about Whitman, Lindsay did, in fact, carry forward Whitman's ideas and values as an integral, if unstable, dimension of that practice. Both as a poet and as a kind of performance artist, I would maintain, Lindsay was part of a significant impetus that had begun with Whitman and which energetically impelled poetry forward in the direction of Kenneth Patchen; Bob Kaufman and the Beats; the tentative rapprochement in the 1950s and 1960s of poetry, popular music, and visual media; and subsequently the poetry slam and hip hop music. ${ }^{33}$

Edgar Lee Masters was chosen to write the authorized biography of Lindsay, and for good reason. He had not only proven a loyal friend to Lindsay, but he was both a fellow Progressive and a recognized poet in his own right. But Vachel Lindsay: A Poet in America was, as it turned out, a distinctly peculiar and disconcerting work. In the interests of candor and objectivity, Masters tore Lindsay down as much as he built him up, and it is his blunt, and even unfeeling, criticisms, in the end, which come to dominate the book. The result is a kind of cracked monument. Yet, for all that, Vachel Lindsay can be instructive and even illuminating. In the book, Masters, who wrote a separate (and mildly compelling) study of Whitman, struggles, as did Lindsay himself, with the question of Whitman's influence on Lindsay's poetry. ${ }^{34}$ Indeed, his biography of Lindsay has almost as much to do with Whitman as with Lindsay himself. Moreover, an extraordinary and puzzling series of inconsistent and even contradictory remarks about the two poets, suggestive of Lindsay's own ambivalence, runs through the entire book like a jagged fault line. One moment, the biographer is waxing indignant at the thought that Lindsay might have been indebted to Whitman in any way at all; the next, he is effusively proclaiming Lindsay to be "a son of Whitman." 35

Whether singing the praises of Lindsay, or giving him a dressingdown (as he so frequently does), Masters is almost always measuring him against Whitman and Whitman's legacy. His assessment culminates in a sloppy, but comprehensive, catalogue of similarities and parallels. "Both men," he asserts, "were enormous egotists, individualists, with a tendency toward the wild and woolly. Whitman ached with sex, and so did Lindsay. One took America for his love and thus sublimated; the other poured out his heart to Mystical Springfield, to religion, Christ, Buddha, and the heroes, and thus consumed emotional energies which conceivably might have taken a Byronic direction" (257). He points to their "like physiological experience," arguing that the two poets "were both natural celibates; both were old men at fifty. Both were victims of the Civil War, and both idolators of Lincoln. Whitman ruined his health 
during his hospital experience, and suffered morally from the despotic tightening of the country when the war was over. Lindsay embraced the era of that war. . . . But at last it was the forces, the culture created by the war which did most to destroy him" (258).

For his part, Lindsay had, in fact, taken a swipe at Whitman from time to time in print. In a review written for Poetry in 1918, for example, he enthused about a collection of poems by American doughboys, called Yanks, pointing to its use of "the easy American dialect of college boys and farm-hands alike" which conjured up the possibility of a "future idiom . . . far from the shackles of Riley, and equidistant from Brobdignagian tyrannies and distensions of Whitman." ${ }^{36}$ As Massa points out, Yanks appealed to Lindsay because "it had no pretensions (as he apparently thought Whitman did) to be aesthetic and stoical; it had a ring of sincerity which he found lacking in Whitman." " In his critical notice, Lindsay goes so far as to say that the anthology "delivers us from Whitman, thank God! If you really want American poetry, I suggest that you forget Whitman a moment and read Yanks" (244).

Lindsay also published an "editorial" on Whitman which was subsequently incorporated into The Litany of Washington Street (1929)..$^{38}$ Whitman claims, in fact, a prominent place in the book's loose assemblage of essays on social and political aspects of American history, done up festively with patriotic wrappings and bows; but the way in which he is presented and discussed sends decidedly mixed signals. On the one hand, Whitman is ensconced in a pantheon of national heroes which includes Washington, Jefferson, and Lincoln, and his status is celebrated accordingly. We are exhorted to observe "solemnly and gaily" Whitman's birthday every May 31, and to do so in the same spirit as those of the country's most hallowed political icons (8-9). Lindsay explicitly praises Whitman, who is "as big a poet as his most emphatic admirer makes him out to be" (55). With more than a hint of irony, he even expresses his willingness to "grant for Whitman's Leaves of Grass everything ever said in its praise by the wildest French critic" (59). Moreover, the book as a whole is, in fact, structured around extensive excerpts from Leaves of Grass; indeed, seven of the fifteen sections which make up The Litany of Washington Street consist entirely of quotations from Whitman.

Yet a sour note has already been sounded on the first page. One of the first remarks Lindsay makes in the prologue is that his Whitman essay sets out "to destroy the Whitman created by the Whitman cult" (2). Hinting at a larger plan of attack, he then suggests that "Whitman was a free-soiler, an active politician throughout his youth, edited political party papers, took our political axioms seriously and slowly developed them in his poetry. ... Aside from his general orthodox United Statesism, he is a Jeffersonian. Without Jefferson, we cannot get Whitman. Therefore I list him among our statesmen, rather than among our literati” (2). 
As if to bolster this view, the excerpts taken from Leaves of Grass exclude almost entirely the personal and spiritual dimensions of Whitman's poetry, and they are even assigned new titles along the lines of "Quotations from Walt Whitman, the Orthodox Millennial Jeffersonian Democrat" (96). In one sense, of course, such a reconfiguration is perfectly defensible. It hearkens back, after all, to the notion that Whitman himself advanced in his lecture of 1851, a notion that was also part and parcel of the socio-aesthetic program of Progressives like Lindsay: the idea that beauty is as much a function of civic virtue and democratic values as anything else. This particular stance towards Whitman's achievement is propped up obliquely by Lindsay's contention that "There were three great ... poets in the very beginning- George Washington, Patrick Henry, and Thomas Jefferson" (14).

But Lindsay's reconfiguration also serves a quite different, and rather more dubious, purpose. It effectively devalues Whitman as a poet and displaces the effect of his literary and aesthetic influence. For Lindsay is, of course, insinuating that Whitman's importance ought to rest largely, and perhaps exclusively, on his status as a political spokesman and eminence. Indeed, Lindsay's parting shot as regards Whitman is: "Remember, he will be, with Jefferson, a statesman, in a thousand years" (64).

The sense that Whitman's iconic reputation as a poet was, in fact, something of a sore point for Lindsay is strongly conveyed in the "editorial" itself. Lindsay makes a number of claims about the Good Gray Poet in the essay, all of them negative and all of them problematic in one way or another. In the first place, he vehemently rejects Whitman altogether as any kind of influence, pushing back against "Those who are impatient with the citizens of the U.S.A. for not surrendering abjectly to Walt Whitman, and producing an army of singers and citizens of the same style" (55). He concedes that "we are fortunate in Sandburg, who owes a direct debt to Whitman, without being destroyed by him" (56). But he then insists that "Sandburg is something more than a Whitmanite. And there is only one Sandburg, not an army of a million singing Sandburgs." As if in anticipation of William Carlos Williams's cautionary adage about Whitman, Lindsay suggests that "He who would have a grand style [like that of Whitman] - must begin again" (57).

In particular, Lindsay resists the idea that Whitman might exert any kind of political or spiritual influence, lashing out against "the thesis of Whitman's followers . . that we must follow him personally" (59). Expatiating on this, he argues that the domain of exemplary writing is one thing, while that of practical experience and exemplary conduct quite another. "Leadership," Lindsay observes, "is seldom the gift of the artists, or we would have gods, and not men, very soon. Buddha did not write. Socrates did not write. It left them the strength to make 
an art out of life" (58). Striking out once again at Whitman's followers, he complains that they "thrust him upon us like Buddha, Prince Siddhartha. What men in history have rightly won a personal devotion? ... St. Francis ... won the allegiance of saints and sinners. But The Little Flowers of St. Francis records a life that was a masterpiece. Whitman's book was a masterpiece, but his life was only half that good" (58).

In fact, Lindsay sees Whitman's life as being fundamentally, and disappointingly, deficient. "I can admire a devil," he explains, "but he must have some salt. I can also admire an angel-but he must have some personal lightning. Not all the personal tales about Whitman equal the single simple narrative of John Randolph, fresh from hunting, marching into Congress . . . with his hound-dogs in front of him" (59). Lindsay is even at pains to argue that Whitman, both as an individual and as a literatus, was out of touch with basic American values as regards gender: "Whitman — both as a man and a poet-fails in his definition of United States democracy in an essential matter. .. . He has no chivalry" (60). Lindsay sees chivalry - by which he means embracing the Victorian concept of femininity - as "one of the indestructible elements that no leveling process has ever wiped out of life"; and he gestures disdainfully in the direction of "all the glad Jezebels of Whitman" $(60,63)$.

The gender-related aspect of Lindsay's position in this regard has been typified as homophobic, and there is, in fact, at least one piece of corroborative evidence to justify this in the documentary record. ${ }^{39}$ However, there is also, as it happens, a sizeable body of evidence pointing to a rather less sinister basis for Lindsay's perspective: namely, an old-fashioned, straight-laced prudery about the human body and bodily functions of the sort which was demonstrably part of Lindsay's devout Christian upbringing, and which could still, in the teens and twenties, exert a suffocating influence.

It will be remembered that Whitman, in a range of once controversial poems with an egalitarian slant, exalted both men and women-ordinary American men and women, at that; and that he went so far as to exalt the plain and ordinary facts of their physiology as well. That is almost certainly what Robert Ingersoll had in his mind when he praised Whitman for proclaiming a "gospel of the body." 40 Lindsay, whose notion of ideal femininity corresponded roughly with the fragile, luminous characters portrayed by Lillian Gish in films such as Broken Blossoms (1919) and The White Sister (1923), would (and could) never have accepted any such "leveling" principle, nor the degree of sexual candor that we associate with Whitman. Hence his stodgy and, for us, mystifying indignation about "Jezebels." Such individuals were doubtless the self-same people that Whitman had referred to as "the noble, plain women I have met . . . tender, wise, pure, high. ${ }^{\prime 1}$ 
Coming back to Lindsay's "editorial" as a whole, it should already be evident that the prevailing winds of the essay are strangely at variance with those of other pieces in The Litany of Washington Street. On the one hand, the book as a whole declares in no uncertain terms that Whitman is to be viewed as just a political figure, not a poet; on the other, the essay itself insists with equal vigor that Whitman was, if anything, merely a poet, and indeed not much of anything else. Plainly, when it came to placing Whitman in any kind of perspective, historical or otherwise, Lindsay was at odds with himself.

In his private correspondence, Lindsay alludes, as one might anticipate, to a broad spectrum of writers. Through his letters, in fact, we acquire a rough familiarity with the literary topography he was acquainted with during the period when he came of age as a poet, a topography whose chief landforms included Kipling and Masefield. But it is to Whitman that Lindsay returns again and again. Writing in 1905 from New York to his favorite high school teacher, his first impulse is to measure his experience of the city with that of Whitman: "There is a whole lot that Whitman did not put in. It is the metallic roar, the terrible overhead railroads, the harshness of it all, that dulls every fine sensibility for the greater part of every day. What little time is left for the soul to live is so little a man cannot read a poem twice." ${ }^{\prime 42}$ And this reflection prompts a remark which, in retrospect, seems almost prescient: "The only way to make [someone] read a poem twice is to construct a jingle haunting as a popular tune, a jingle that can almost be whistled. And that is a forlorn hope. I am going to think it over"(8).

The emotional register, in some instances, is one of outright veneration, as in a letter which honors Isadora Duncan: "We are for her because she dreamed that her little son might write noble United States poetry that might of itself be danced, the Song of the United States and Whitman" (152). More typically, however, Lindsay's praise is configured in such a way as to intimate his doubts and reservations. In 1917, writing to Carl Sandburg, Lindsay exhorts American poets to stop bickering and speak with one unified voice: "If all the critics in the United States shouted at once through one megaphone, our next door neighbor would not hear [us], and Whitman would not be vindicated" (142). But he then proceeds to qualify this implicit (and ringing) endorsement of Whitman's significance: "I still think more of Poe than Whitman. ... I suppose the ideal American poet would have the tang of Mark Twain, the music of Poe, the sweep and mysticism of Whitman, and the platform power of Bryan, and a career in verse similar to his in Politics" (142). Elsewhere Lindsay chides Louis Untermeyer for using "Whitman to the limit in your last critical work" and urges on him a shift in perspective: "I have said for years that if almost everything that was said in praise of Whitman was rewritten with the names of Johnny 
Appleseed and Abraham Lincoln alternately substituted, it would be much truer in the eyes of the real open mind of America" (193-194).

Some of Lindsay's most elaborate comments on Whitman appear in letters to Stephen Graham, his congenial British crony and hiking companion, but these characteristically have a mildly negative cast: "[Mark Twain] breathes the real American continent far more than professional avowed weather, bird and beast writers like John Burroughs or Walt Whitman. ... Whitman speaks of the American as he chose to imagine him, but Mark Twain is the American, as actually found, epic in a subtler sense, for he had an epic crowd laughing with him, they knew not why" (224). Here as elsewhere, Lindsay is simply unable to resist the temptation to tweak the noses of Whitman's admirers: "[Frank Waller Allen] is a Hedonist right where I begin to hate it, a psycho-analyst, which thing I cannot abide, and a Whitmanite which makes me very tired" (189).

The sharpest and most dramatic expression of Lindsay's ambivalence about Whitman takes the form of a lengthy postscript to a love letter composed in 1923. Lindsay confides to the object of his affections (who is addressed in terms worthy of an Arthurian damsel) that "Walt Whitman is a great poet, and I am not" (297). The critics, he goes on to explain, want him to be a modern Whitman, but he is obliged to demur: "They pour all America into my lap and beg me to sing about it. I cannot" (297). At this point, Lindsay makes what is, for us, a disheartening disclosure: "Well - I always considered Whitman as a man and a citizen a genius, but [also a] rather crooked and shabby old man with a streak of perversion. I can forgive this, but it keeps the American people from finding leadership in him. I never mention it out loud. But it spoils him for a model for me" (297).

On the one hand, Lindsay cheerfully concedes (to his lady fair) that "In the matter of Democracy, the world has with the help of such as Whitman made tremendous progress" (299). On the other, he develops at great length an argument that we have already scrutinized, viz., that the absence of "chivalry" in Whitman's social vision constitutes an irremediable handicap (298-299). Lindsay is also at pains to contrast favorably his own career with that of the Good Gray Poet. "Whitman," he claims, "never saw the America I have seen and loved. The [people] who came in to hear me could total half a million or a million - if my audiences were added up these ten years" (297). In a culminating passage which manages to externalize, by turns, honest praise, lofty condescension, and a kind of adolescent defiance, Lindsay goes so far as to suggest that "Whitman in his wildest dreams was only a pretended troubadour. He sat still in cafés - never such a troubadour for audiences as Bryan or a thousand Chautauqua men. He was an infinitely more skillful writer than any other American. But I can beat him as troubadour" (298). 
Earlier on, I discussed a sense of aesthetic hesitation conveyed by the two transitional poetic excerpts which accompanied Whitman's lecture in 1851. It would scarcely come as a surprise, of course, if a roughly similar ambivalence or vacillation were to be identified in the thinking and textual practice of transitional poets like the Progressives; and that is, in fact, decidedly what we find in Lindsay's case. It will be recalled, in this context, that some of the most prominent Progressives, such as Edwin Arlington Robinson and Robert Frost, while profoundly indebted to Whitman, did not opt for vers libre. What such poets did was to shift the poem's center of gravity in the direction of a plain and straightforward conversational discourse, with the result that metrical constraints and rhyming patterns became more discreet and muted, and the poem itself could sound relatively unstructured. The way in which Lindsay came to terms with Whitman on the level of technical practice was analogous, involving a special hesitational dynamic he worked out on his own - an idiosyncratic form of constrained looseness especially suited to oral performance. It entailed a particular amalgam of elasticity, high-voltage energy, and popular appeal which no other American poet of his generation succeeded in producing.

In a remarkable essay addressing this question, Austin Warren has contended that Lindsay's poetry was grounded in a contrastive and dynamic interplay between the sensibilities of Poe and Whitman. "The chief Lindsay poems," he asserts, "might be genealogically understood in terms of 'The Bells' and 'The Raven,' 'When Lilacs Last' and 'O Pioneers.' Poe is suggested by Lindsay's fondness for onomatopoeic effects and the more obvious phonetic devices (strongly marked rhythms, plentiful rhyme, alliteration); Whitman, by the search for an American myth, a democratic tradition made imaginative." ${ }^{33}$ On the level of prosody, Warren argues persuasively that Lindsay's signature technical breakthrough involved the use of dipodic meter, which has its roots in popular balladry and nursery rhymes, and is related to public performance and emphatic sing-song rhythms (87-89). (As it happens, dipodic meter has also been identified as the metrical engine driving hip-hop music.)

Lindsay was, in fact, part of a "dipodic movement" whose adherents included Kipling and Masefield, and whose goal was to revitalize the poem and drastically expand its popular appeal. The overall result was not just an innovative kind of "chant-poetry," but something truly remarkable which is still readily perceptible in poems such as "The Kallyope Yell." In Lindsay's hands, the traditional metrical structure of the verse acquired a remarkable looseness and freedom; and poetry itself became a muscular, agile form wearing a loose uniform of metrical and rhyming constraints. The kind of poem he devised was at once traditional and experimental; constrained and free; both coarse and 
sophisticated - and it brought him within hailing distance, at least, of Whitman's own "chant-poetry" and of the precincts of free verse itself.

In more general terms, Warren characterizes Lindsay both as a special kind of folk-artist (a cross, perhaps, between an orator and a folksinger) and as a middle-brow outsider whose efforts to become a high-brow canonical figure were never entirely successful. For Warren, Lindsay's career was, in the last analysis, chiefly significant as part of a transitional linkage, as a pylon in the historical span connecting nineteenth-century poets like Whitman with the modern era. "The movement of American culture," he suggests, "passes through Lindsay: his is a historic moment of participation; many lines pass through him and go on" (93).

Given such comments, it is curious, to say the least, that there should be a reference to Lindsay in a contemporary Latin-American novel pertaining, in fact, to the future rather than the past. In Amulet (1999), Roberto Bolaño, the prodigious Chilean writer, places a bold and dramatic prediction in the mouth of his protagonist, who is a progressive academic with a passionate attachment to young poets and new, innovative poetry. "Vachel Lindsay," she proclaims, "shall appeal to the masses in the year 2101." ${ }^{\prime 4}$ For us, needless to say, Lindsay's cultural standing and prospects seem neither so certain nor so bright. While Whitman's status as a classic seems to grow and solidify with every passing year, that of Lindsay, once imposing, has dwindled now almost to the vanishing point.

In 2003, as if to underscore this state of affairs, two fledgling American poets released a spoken word recording called Adventures While Preaching the Gospel of Beauty. ${ }^{45}$ Not only had the poets appropriated the title of one of Lindsay's books, but they had also reenacted (in 2002 and on a small scale) one of Lindsay's "tramps" across country, improvising poems for a number of impromptu public readings given at stops along their way. The end result is, if anything, a predictable embodiment of the postmodern aesthetic, in the sense that it is ance a half-hearted, self-deprecatory exercise in poetic idealism and a kind of limp, deflated prank. The recorded poems themselves are, without question, honest and reputable examples of contemporary free verse, but they are also so homogenized and innocuous that even the longdiscredited "genteel poetry" of the 1890s could seem almost vigorous by comparison. Whatever might be said at this point, in a constructive spirit, about the conjunction of postmodernity and the anxiety of influence, such a tribute does not seem at all positive or auspicious. The Lindsay who wandered through the American countryside so many years ago, and who actually preached a gospel of beauty, would scarcely have been gratified. 
Walt Whitman himself was not always sanguine, of course, about the future. On one occasion, in 1888, while being interviewed by some college students, he actually advised them to steer clear of poetry altogether. ${ }^{46}$ Yet he hoped against hope for a prospective lyrical practice which would be robustly forward-looking, broad in its conception, and reflective of modernity, and which would, among other things, "illustrate the people and respond to the slang, the folkways, the vast spectacle of the expanding country." ${ }^{47}$

It was simply not for him to know, in the end, what Vachel Lindsay and a new generation of poets would attempt to do in order to advance precisely those ends. However problematic and contradictory his reception of Whitman, Lindsay would help, in fact, to prepare the ground for the Good Gray Poet's values and program, aesthetic and otherwise, in the emerging era of modernism. However galling his frustrations at the end, he would also succeed in cultivating a modest, but fertile, "poetry patch" of his own, and in espousing a bracing vision of social change. Above all, both as a poet and an American, he would never entirely lose sight of the bar he had set for himself: "The mandate . . for the artist is the same as for the nation. 'Live like the sparrow. Be yourself completely. Utter your soul, regardless of cost." "'48

Coe College

\section{NOTES}

1 I am indebted to Ed Folsom, whose forbearance, encouragement, and sound advice are part of the fabric of this essay.

2 Walt Whitman, Leaves of Grass: Comprehensive Reader's Edition, ed. Harold W. Blodgett and Sculley Bradley (New York: New York University Press, 1965), 14. Hereafter, $L G$.

3 Whitman, Prose Works 1892, ed. Floyd Stovall (New York: New York University Press, 1964), 2:412-413.

4 Lisa Szefel, The Gospel of Beauty in the Progressive Era: Reforming American Verse and Values (New York: Palgrave Macmillan, 2011), 57-58. Hereafter, GoB.

5 Vachel Lindsay, Adventures While Preaching the Gospel of Beauty (New York: Mitchell Kennerley, 1914). See also Howard Means, Fohnny Appleseed: The Man, the Myth, the American Story (New York: Simon and Schuster, 2011).

6 Quoted in Szefel, GoB, 4.

7 Whitman, "Art and Artists" in The Uncollected Poetry and Prose of Walt Whitman, ed. Emory Holloway (Garden City, New York: Doubleday, Page and Company, 1921), 1:243. Hereafter, UPP.

8 Quoted in Szefel, GoB, 99. The phrase is taken from a critique of Lindsay's Rhymes To Be Traded for Bread in Current Opinion 55 (August 1913), 128. 
9 Gay Wilson Allen, The Solitary Singer (Chicago: University of Chicago Press, 1985), 110.

10 See Bruce Weirick, From Whitman to Sandburg in American Poetry: A Critical Survey (New York: Macmillan, 1924). While acknowledging that Whitman's spirituality "partook of many of the transcendental elements of his predecessors," Weirick makes the point that it was "nevertheless original, as all mysticism is when reflected through the medium of a powerful personality" (16). After a lapse of more than eighty years, Weirick's grasp of Whitman's character and outlook continues to be reliable, and his take on Vachel Lindsay is as perceptive as it is level-headed (204-210). Moreover, Weirick's detailed explanation of the linkage between Whitman and the poets of the Progressive Era remains a useful point of departure. One familiar, and still intriguing, thread of his argument is that minor (but popular) poets such as John Hay, Bret Harte, Will Carleton, and James Whitcomb Riley communicated some of Whitman's most basic priorities (such as the depiction of American life in colloquial language) to a broad readership, and that they effectively kept such priorities in play until more gifted poets were ready to embrace them (41-68).

11 Raymond Nelson, Kenneth Patchen and American Mysticism (Chapel Hill: University of North Carolina Press, 1984), 6. Hereafter, KP.

12 See also Whitman, UPP, $222 \mathrm{ff}$.

13 Herman Melville, The Confidence-Man (London: Penguin, 1990), 197; and footnote, 329. Hereafter, $C M$.

14 Vachel Lindsay, Collected Poems (New York: Macmillian, 1925), 71-76.

15 Hazelton Spencer, "The Life and Death of a Bard" in Profile of Vachel Lindsay, ed. John T. Flanagan (Columbus, OH: Charles E. Merrill, 1970), 41.

16 Vachel Lindsay, The Golden Book of Springfield (Chicago: Charles H. Kerr, 1999), 7. Hereafter, Golden Book.

17 Quoted in Ann Massa, Vachel Lindsay: Fieldworker for the American Dream (Bloomington: Indiana University Press, 1970), 38. Hereafter, VL.

18 Quoted in Massa, VL, 87.

19 See Eleanor Ruggles, The West-Going Heart: A Life of Vachel Lindsay (New York: W.W. Norton, 1959), 90-92, 107-108, 177-178. Hereafter, WGH.

20 Quoted in Massa, VL, 91.

21 Szefel, $G o B, 1-2,32-41$.

22 Quoted in Nelson, KP, 14.

23 Szefel, GoB, 121-122.

24 Anne Hempstead Branch, quoted in Ruggles, WGH, 152.

25 Quoted in Ruggles, WGH, 161.

26 From a review which appeared in the Providence fournal (October 1928). Quoted in Ruggles, $W G H, 385$.

27 Conrad Aiken, "Vachel Lindsay," in Profile Of Vachel Lindsay, 3-5. 
28 Vachel Lindsay, The Letters of Vachel Lindsay, ed. Marc Chénetier (New York: Burt Franklin and Company, 1979), 446. Hereafter, Letters.

29 See Richard Schickel, D.W. Griffith: An American Life (New York: Simon and Schuster, 1984) and Lillian Gish with Ann Pinchot, The Movies, Mr. Griffith and Me (Englewood Cliffs, N.J.: Prentice-Hall, 1969).

30 Quoted in Ruggles, WGH, 418.

31 Quoted in E. L. Masters, Vachel Lindsay: A Poet in America (New York: Biblo and Tannen, 1969), 364. Hereafter, PiA.

32 For a recent expression of this view, see Tyler Hoffman, "The Ordeal of Vachel Lindsay" in American Poetry in Performance: From Walt Whitman to Hip Hop (Ann Arbor: University of Michigan Press, 2011), 55-87; hereafter AP. Hoffman casts a distinctly cold eye on Lindsay's accomplishments. His focus is on Lindsay as a quixotic failure and a suicide whose problematic career as a "platform performer" is part of a historical line of development in the United States. He appears to have little use for Lindsay otherwise, and the overall tenor of his assessment is skeptical, if not dismissive.

33 See Bryan K. Garman, A Race of Singers: Whitman's Working-Class Hero from Guthrie to Springsteen (Chapel Hill: University of North Carolina Press, 2000). See also Hoffman, American Poetry in Performance.

34 E. L. Masters, Whitman (1937; rpt. New York: Biblo and Tannen, 1968).

35 Masters, PiA, 39, 60, 226, 324-325.

36 Quoted in Massa, VL, 244. The remarks appeared in Poetry 13 (October 1918/ March 1919), 329-330.

37 Massa, $V L, 244$.

38 Vachel Lindsay, "The Loneliness of Walt Whitman, Statesman-poet," in The Litany of Washington Street (New York: Macmillan, 1929), 54-64.

39 See Hoffman, AP, 56-57.

40 Robert G. Ingersoll, "Liberty in Literature," appendix to Horace Traubel, With Walt Whitman in Camden, Fuly 7, 1890-February 10, 1891 (Carbondale: Southern I1linois University Press, 1990), 7: 468. Hereafter, WWC.

41 Quoted in Traubel, WWC, 7:440.

42 Lindsay, Letters, 7.

43 Austin Warren, "The Case of Vachel Lindsay" in Profile of Vachel Lindsay, 81-93.

44 Roberto Bolaño, Amulet, translated by Chris Andrews (New York: New Directions, 2006), 159.

45 Joshua Beckman and Matthew Rohrer, Adventures While Preaching the Gospel of Beauty (Richmond, Virginia: Verse Press, 2003). [CD.]

46 See Nicole Kukawski, "Whitman's Advice to New Jersey State Scholars: An Unknown Interview," Walt Whitman Quarterly Review 23 (Summer/Fall 2005), 55.

47 Richard Chase, Walt Whitman Reconsidered (New York: William Sloane, 1955), 161.

48 Lindsay, Golden Book, 31. 